\title{
PREVALENCE OF THYROID DISORDERS IN THE COASTAL PLAINS OF ALAPPUZHA, KERALA
}

\author{
Karthika M11, Jeena Ramesh ${ }^{2}$
}

${ }^{1}$ Assistant Professor, Department of Community Medicine, Government T. D. Medical College, Alappuzha. ${ }^{2}$ Assistant Professor, Department of Community Medicine, Government T. D. Medical College, Alappuzha.

\section{ABSTRACT}

\section{BACKGROUND}

Even in the post iodisation phase, thyroid diseases are prevalent. This is seen even in coastal areas. Factors other than iodine deficiency may be responsible for this. Keeping this in mind, a study was planned to estimate the prevalence of Thyroid disorders in the Ambalappuzha North grama panchayath area of Alappuzha, Kerala. Local self-government supported this by providing sufficient funds for estimating the serum TSH level of all the participants.

\section{MATERIALS AND METHODS}

A camp-based cross-sectional study was conducted in the area. 10 camps were conducted at different areas ensuring maximum participation. A total of 1711 individuals participated in various camps. Serum TSH level was estimated in the initial camp. For those who had abnormal TSH value, separate camps were arranged for estimating T3 and T4 levels.

\section{RESULTS}

86.7\% had normal TSH level whereas 9.6\% had increased TSH level and 3.7\% had decreased TSH level. It was also seen that as age increases the chance of developing hypothyroidism also increases. There was also a significant difference among males and females. But there was no statistically significant difference among coastal and non-coastal areas of the same panchayath.

\section{CONCLUSION}

Even after universal iodisation, thyroid disorders are prevalent in Ambalappuzha North gram panchayath.

\section{KEYWORDS}

Thyroid Disorders, Prevalence, Post Iodisation, Coastal Area.

HOW TO CITE THIS ARTICLE: Karthika M, Ramesh J. Prevalence of thyroid disorders in the coastal plains of Alappuzha, Kerala. J. Evolution Med. Dent. Sci. 2017;6(77):5471-5473, DOI: 10.14260/Jemds/2017/1187

\section{BACKGROUND}

India adopted universal salt iodisation programme in 1983. But even with usage of iodised salt, thyroid disorders are not coming down in India. This is prevalent even in coastal regions where fish consumption is more when compared to other areas. There may be factors other than Iodine deficiency responsible for goitre. Thyroid autoimmunity and goitrogens like thiocyanate have been implicated in these cases of goitre. Increase in autoimmune thyroiditis after iodisation has been recorded in other countries as well. ${ }^{2}$

Thyroid disorders - clinical as well as subclinical-is found to be increasing in areas of Ambalappuzha North gram panchayath. This area is under the control of Department of Community Medicine, Government T. D. Medical College, Alappuzha and the health projects of the Panchayath are implemented by Administrative Medical Officer who is an Assistant Professor in the Department of Community Medicine. During the year 2013, in the meeting of working group members which is the initial meeting for making new projects for panchayath, the issue of thyroid disorders was

Financial or Other, Competing Interest: None.

Submission 03-08-2017, Peer Review 11-09-2017,

Acceptance 19-09-2017, Published 25-09-2017.

Corresponding Author:

Dr. Karthika $M$,

Assistant Professor,

Department of Community Medicine,

Government T. D. Medical College, Alappuzha.

E-mail: drkarthikam@gmail.com

DOI: $10.14260 /$ jemds $/ 2017 / 1187$ raised. A project was proposed for screening for thyroid disorders and treatment for the same. Panchayath kept an amount of Rs. 3.5 lakhs for implementation of the project. Medical Officer put forward the project and was approved by District Medical Officer.

The data obtained after implementation of the project is the basis for this study.

\section{Objectives}

To estimate the prevalence of Thyroid disorders in the Ambalappuzha North gram panchayath area of Alappuzha, Kerala.

\section{MATERIALS AND METHODS}

Study Design- Cross-sectional study.

Study Setting- Ambalappuzha North gram panchayath with a total population of 54000, consists of 18 wards, of which 7 wards are coastal.

\section{Methodology}

10 camps were conducted in different areas of the panchayath, in such a way that one camp was arranged for 2 wards, accessible to people of both wards. Bit notices with a short discussion of thyroid diseases were distributed to all the houses with the help of field staff and ASHA workers showing the date and venue of the camps, to ensure maximum participation. Announcement was also given in the newspapers.

Venue selected for the camps were subcentres, anganwadis, etc, where accessibility is assured. Attendance for each camp varied from 150 to 200 adding to a total of 
around 1720. Participants were examined by medical officers and sent for screening test which was arranged in the venue itself.

IEC approval for conducting the study at block level was obtained from Institutional Ethics Committee of our college.

At the time of distribution of bit notice, the residents were informed about the intention of conducting the camp and those willing to participate were asked to register at the camp site.

$5 \mathrm{~mL}$ of venous blood was collected from all the patients, for estimation of Serum TSH, which was done using CLIA test (Chemiluminescence Immunoassay). After obtaining the result, the patients were grouped into two, those with normal TSH and those with abnormal TSH. The results were distributed to the participants by field staff. For those with abnormal TSH values, two subsequent camps were conducted on dates which was announced early.

\section{Inclusion Criteria}

All people who attended the camps were included.

\section{Analysis}

Data was entered in MS office excel spread sheet and analysed using SPSS statistical software version 16.

Quantitative variables were summarised using mean and standard deviation and qualitative variables using proportion. Appropriate tests of significance like $\mathrm{X}^{2}$ was done to find out the association between thyroid disorders and selected factors.

\section{RESULTS}

A total of 1711 were examined from 10 camps conducted in the area. Results were analysed using SPSS version 16.

\section{Age Distribution of the Individuals}

As seen in the table, majority were in the age group of 16 to 60 years.

\begin{tabular}{|c|c|c|}
\hline Age group (Yrs.) & Frequency & Percentage \\
\hline $0-5$ & 22 & 1.3 \\
\hline $6-15$ & 131 & 7.7 \\
\hline $16-60$ & 1434 & 83.8 \\
\hline$>60$ & 124 & 7.2 \\
\hline Total & $\mathbf{1 7 1 1}$ & $\mathbf{1 0 0}$ \\
\hline \multicolumn{2}{|c|}{ Table 1. Age Distribution of the Individuals } \\
\hline
\end{tabular}

\section{Gender Distribution}

Of the 1711 individuals, $251(14.7 \%)$ were male and 1460 $(85.3 \%)$ were female.

\section{Biochemical Parameters}

Serum TSH was investigated for all the people who attended the camp. Those who showed abnormal TSH value were asked to review for $\mathrm{T} 3$ and $\mathrm{T} 4$ estimation.

\begin{tabular}{|c|c|c|}
\hline TSH value & Frequency & Percentage \\
\hline Normal $(0.30-5.5)$ & 1483 & 86.7 \\
\hline Increased $(>5.5)$ & 165 & 9.6 \\
\hline Decreased $(<0.3)$ & 63 & 3.7 \\
\hline Total & $\mathbf{1 7 1 1}$ & $\mathbf{1 0 0}$ \\
\hline \multicolumn{2}{|c}{ Table 2. TSH Results } \\
\hline
\end{tabular}

As shown in the table, $86.7 \%$ of the population were euthyroid, 9.6\% were diagnosed with hypothyroidism and $3.7 \%$ with hyperthyroidism. That means, in Ambalappuzha North gram panchayath, the prevalence of thyroid disorders from the current study was $13.3 \%$ (CI- $12.8-13.7$ ).

\begin{tabular}{|c|c|c|c|c|}
\hline $\begin{array}{c}\text { Age } \\
\text { Group }\end{array}$ & Normal & Hyperthyroid & Hypothyroid & Total \\
\hline $0-5$ & $\begin{array}{c}21 \\
(95.5 \%)\end{array}$ & 0 & $1(4.5 \%)$ & $\begin{array}{c}22 \\
(100 \%)\end{array}$ \\
\hline $6-15$ & $\begin{array}{c}122 \\
(93.1 \%)\end{array}$ & $2(1.5 \%)$ & $7(5.3 \%)$ & $\begin{array}{c}131 \\
(100 \%)\end{array}$ \\
\hline $16-60$ & $\begin{array}{c}1242 \\
(86.6 \%)\end{array}$ & $52(3.6 \%)$ & $140(9.8 \%)$ & $\begin{array}{c}1434 \\
(100 \%)\end{array}$ \\
\hline$>60$ & $\begin{array}{c}98 \\
(79 \%)\end{array}$ & $9(7.3 \%)$ & $17(13.7 \%)$ & $\begin{array}{c}124 \\
(100 \%)\end{array}$ \\
\hline Total & $\begin{array}{c}\mathbf{1 4 8 3} \\
(\mathbf{8 6 . 7 \% )}\end{array}$ & $\mathbf{6 3}(\mathbf{3 . 7} \%)$ & $\mathbf{1 6 5}(\mathbf{9 . 6} \%)$ & $\mathbf{1 7 1 1}$ \\
\hline \multicolumn{5}{|c|}{ Table 3. Age Group and TSH Value } \\
\hline
\end{tabular}

X2 value $-13.69 \mathrm{df}-6 \mathrm{P}$ value -0.03

There is a significant association between age and thyroid diseases.

As age increases the chance of developing thyroid diseases also increases.

\begin{tabular}{|c|c|c|c|c|}
\hline Gender & Normal & Hyperthyroid & Hypothyroid & Total \\
\hline Male & $\begin{array}{c}229 \\
(91.2 \%)\end{array}$ & $2(0.8 \%)$ & $20(8 \%)$ & $\begin{array}{c}251 \\
(100 \%)\end{array}$ \\
\hline Female & $\begin{array}{c}1254 \\
(85.9 \%)\end{array}$ & $61(4.2 \%)$ & $145(9.9 \%)$ & $\begin{array}{c}1460 \\
(100 \%)\end{array}$ \\
\hline Total & $\begin{array}{c}\mathbf{1 4 8 3} \\
(\mathbf{8 6 . 7 \% )}\end{array}$ & $\mathbf{6 3}(\mathbf{3 . 7} \%)$ & $\mathbf{1 6 5}(\mathbf{9 . 6 \% )}$ & $\begin{array}{c}\mathbf{1 7 1 1} \\
\mathbf{( 1 0 0 \% )}\end{array}$ \\
\hline \multicolumn{5}{|c|}{ Table 4. Gender and TSH Value } \\
\hline
\end{tabular}

\section{$\mathrm{X} 2-8.21 \mathrm{df}-2 \mathrm{P}$ value- 0.016}

As seen from the table, there is a significant association between gender and thyroid diseases. Females are more prone to thyroid diseases when compared to males.

\section{Mean TSH Values}

There were 1483 individuals with normal TSH values. Values ranged from 0.30 to 5.48 with a median of 2.11. Median value in the hyperthyroid group was 0.04 . Values ranged from $<0.01$ to 0.27 . There were 165 cases in the hypothyroid group. Values ranged from 5.5 to $>151$ with a median of 8.7.

\section{T3 and T4 Estimation}

1711 individuals attended initial camps of which 228 persons had abnormal TSH values. Another camp was conducted for these persons. But only 114 people attended. 48 of them showed normal T3 and T4 values, 18 had elevated values and 48 had decreased values. There is a negative correlation between $\mathrm{T} 3$ and T4 values and TSH values.

\section{Coastal and Non-coastal Areas}

Panchayath has 17 wards of which 7 wards are coastal. A total of 1711 people were tested, of which 957 (55.9\%) live in coastal areas and the rest $754(44.1 \%)$ live in non-coastal areas. 
Analysis was done to find out whether there is difference between coastal and non-coastal areas in thyroid status. Mean TSH value of the coastal group was 4.23 with a S.D. of 12.96 whereas for the non-coastal group it is 3.92 and 11.75 respectively. In the coastal area, out of 957 tested, 821 $(85.7 \%)$ showed normal value, $36(3.8 \%)$ had TSH value in the hyperthyroid range and $100(10.4 \%)$ in the hypothyroid range. Corresponding values in the non-coastal area are 662 (87.8\%), $27(3.6 \%)$ and $65(8.6 \%)$. But the difference in frequency of these values were not found to be statistically significant.

\section{Clinical Features of the Study Subjects}

Even though all the subjects who attended the camp were seen by medical officers, only around 70 had clinical features suggestive of hypothyroidism like weight gain, menstrual irregularities, etc. and around 15 had symptoms suggestive of hyperthyroidism like palpitation, weight loss, etc.

\section{DISCUSSION}

Studies were conducted in other parts of India and abroad to find out the prevalence of thyroid disorders. In the present study, $86.7 \%$ of the population were euthyroid, $9.6 \%$ were diagnosed with hypothyroidism and $3.7 \%$ with hyperthyroidism which means, in Ambalappuzha North gram panchayath the prevalence of thyroid disorders was $13.3 \%$ (CI- 12.8 - 13.7). Another study conducted by Usha Menon et al in South India showed that thyroid function abnormalities were present in $19.6 \%$ of subjects.(3) A study conducted in eight cities of India by Ambika Gopalakrishnan Unnikrishnan et al showed overall prevalence of hypothyroidism as $10.95 \%$ which is almost similar to our study.(4)

In our study, there is a significant association between age and thyroid disease.

The study by Ambika Gopalakrishnan Unnikrishnan et al also showed the same result.(4) The study conducted by Vaishali Deshmukh et al pointed out that prevalence of thyroid autoimmunity increases after the age of 35 years. (5)

Many studies have shown that there is a significant association between gender and thyroid diseases. In our study also, it was proved that females are more prone to thyroid diseases when compared to males. The study by Desai et al in India also showed a marked female predominance.(6) The study conducted by Akhil Bandhu Biswas also showed the same result.(7) The study by Knudsen $\mathrm{N}$ et al in Denmark showed the presence of thyroid peroxidase antibody was more among females compared to males. ${ }^{(8)}$ The study done in Sub Saharan Africa by Sidibe et al also had female predominance.(9)

Our study could not find a statistically significant difference in frequency of thyroid disorders among coastal and non-coastal areas. But in the study by Ambika Gopala Krishnan et al, there is a statistically significant increase in hypothyroidism in inland cities compared to coastal cities.(4)

\section{Limitations of the Study}

1. As it is a camp-based study, those who attended the camp were only included, hence generalisability may be a limitation.
2. Inability to analyse a few blood samples due to inadequate sample is another limitation of the study.

\section{CONCLUSION}

In Ambalappuzha North gram panchayath, in spite of Iodine prophylaxis through the salt iodisation programme there is persistence of thyroid disorders especially hypothyroidism. A detailed study may be conducted in the area to find out the risk factors associated like autoimmune thyroiditis, goitrogens, environmental Iodine content, etc. The National Iodine deficiency disorders control programme may also be fine-tuned depending upon the detailed multi centric study.

\section{ACKNOWLEDGEMENTS}

1. President and other elected representatives of Ambalappuzha North gram panchayath for supporting the project.

2. Field Staff including ASHA workers who worked in the area for making the project a success.

\section{REFERENCES}

[1] Marwaha RK, Tandon N, Gupta N, et al. Residual goitre in the post iodization phase: iodine status, thiocyanate exposure and autoimmunity. Clin Endocrinol (Oxf) 2003;59(6):672-81.

[2] Bastemir M, Emral R, Erdogan G, et al. High prevalence of thyroid dysfunction and autoimmune thyroiditis in adolescents after elimination of iodine deficiency in the Eastern Black Sea Region of Turkey. Thyroid 2006;16(12):1265-71.

[3] Menon SV, Sundaram KR, Unnikrishnan AG, et al. High prevalence of undetected thyroid disorders in an iodine sufficient adult south Indian population. J Indian Med Assoc 2009;107(2):72-7.

[4] Unnikrishnan AG, Kalra S, Sahay RK, et al. Prevalence of hypothyroidism in adults: an epidemiological study in eight cities of India. Indian J Endocrinol Metab 2013;17(4):647-52.

[5] Deshmukh V, Behl A, Iyer V, et al. Prevalence, clinical and biochemical profile of subclinical hypothyroidism in normal population in Mumbai. Indian J Endocrinol Metab 2013;17(3):454-9.

[6] Desai MP. Disorders of thyroid gland in India. Indian J Pediatr 1997;64(1):11-20.

[7] Biswas AB, Das DK, Chakraborty I, et al. Goitre prevalence, urinary iodine and salt iodization level in sub-Himalayan Darjeeling district of West Bengal, India. Indian J Public Health 2014;58(2):129-33.

[8] Knudsen N, Jorgensen $\mathrm{T}$, Rasmussen $\mathrm{S}$, et al. The prevalence of thyroid dysfunction in a population with borderline iodine deficiency. Clin Endocrinol (oxf) 1999;51(3):361-7.

[9] Sidibe el H. Thyroid diseases in sub-Saharan Africa. Sante 2007;17(1):33-9. 